Nesterovych V. Improvement of Legal regulation of the Public Examination of the Activities of local Self-government in Ukraine

The article reveals the question of improvement of legal regulation of the public examination of the activities of local self-government in Ukraine. The author points out that the constitutional and legal regulation of public examination began in certain areas of activity of public authorities from the very first years of independence of Ukraine. Conducting public expertise is an important form of interaction between the public and local authorities in the adoption of legal acts, contributes to attracting various social and corporate groups to peer review not only the activities of local governments, but also their decisions and the consequences of their implementation. The article notes that the most vulnerable issue in the legal regulation of public examination of the activities of local governments is its insufficient legal certainty at the level of legislative acts.

The author concludes that public expertise of the activities of local self-government bodies is the property of modern democracy. Public expertise of the activities of local selfgovernment bodies means carrying out by the public of a comprehensive study in the form of analysis, evaluation and forecasting of the results of activity or inactivity of local selfgovernment bodies, the effectiveness of their adoption and implementation of decisions. The purpose of the public examination is to prepare a substantiated expert opinion with concrete proposals for the solution of socially important problems for their further consideration by the local self-government bodies in their work. Conducting a public examination is a necessary form of interaction between the public and local self-government bodies when adopting regulatory and legal acts. Conducting public examination helps to attract various social and corporate groups to the expert assessment of not only the activities of local selfgovernment bodies, but also the decisions taken by them and the consequences of their implementation.

Key words: legal regulation, public expertise, public, public authorities, local authorities, Ukraine.

УДК 342.8

Пекарчук В.М. доктор історичних наук, доцент, професор кафедри теорії та історії держави і права, конституизійного права Академї̈ Державної пенітенціарної служби

(м. Чернігів, Україна)

Пекарчук А.В.

студентка 2 курсу Інституту прокуратури та кримінальної юстиції Національного юоридчного університету імені Ярослава Мудрого

(м. Харків, Україна)

\title{
ТРАНСФОРМАЦІЯ ВИБОРЧОЇ СИСТЕМИ ВЕРХОВНОЇ РАДИ УКРАЇНИ ПЕРІОДУ НЕЗАЛЕЖНОСТІ
}

У статті на основі різнопланових джерел досліджуються актуальні питання виборчої системи до вітчизняного парламенту упродовж сучасного періоду незалежності, і на цій основі запровадження більш ефективної моделі пропорційної виборчої системи 3 відкритими списками. Проаналізовано недоліки на різних етапах становлення та розвитку парламентської виборчої системи. Обгрунтовано важливість невідкладного ухвалення Виборчого кодексу

(C) Пекарчук B. М.,

Пекарчук А. В., 2019 
України для створення єдиних позицій забезпечення нормативного регулювання інституту виборів.

Ключові слова: Верховна Рада України, вибори, виборча система, закон, виборчий процес, парламент, виборчий бар'єр.

Постановка проблеми. Випереджаючи час, сьогодні окремі соціологічні групи оприлюднюють рейтинги різних політичних сил не лише на березневі президентські вибори, а й на жовтневі парламентські. I дійсно, 3 огляду на форму державного правління - змішана парламентськопрезидентська республіка - на формування майбутнього нового уряду в Україні наприкінці поточного року суттєво вплинуть саме результати виборчих перегонів до вітчизняного парламенту. Попри те, що в нашій державі відбудуться чергові вибори народних депутатів Верховної Ради України дев' ятого скликання, немає підстав констатувати усталеність засад і повну відповідність практик вітчизняного парламентаризму світовим стандартам. Вирішення проблем зменшення відчуження між громадянами і владою, підвищення довіри до інституту виборів, мотивація безпосередньої участі в них тісно пов'язані з реформуванням виборчої системи загалом і системи виборів органу законодавчої влади, зокрема. Зазначене потребує аналізу змін і механізмів обрання депутатів українського парламенту впродовж періоду незалежності для виокремлення й розвитку позитивних напрацювань, які сприятимуть дальшому вдосконаленню законодавчого забезпечення виборчої системи Верховної Ради України.

Аналіз останніх досліджень і публікацій. Питання становлення та реформування виборчої системи до Верховної Ради України розглянуто в низці публікацій. Серед науковців, які займалися висвітленням аспектів виборчої системи, ії нормативно-правового забезпечення, згадаємо таких провідних вітчизняних учених та практиків, як Н. Богашова, Ю. Ключковський, М. Козюбра, С. Конончук, В. Литвин, О. Мазур, О. Петришин, Б. Райковський, М. Рябець, А. Романюк, О. Святоцький, М. Ставнійчук, А. Ткачук, О. Тодика, В. Шаповал та інші. Водночас перед суспільством 3'являються нові проблеми, які потребують глибокого опрацювання та вирішення 3 обов'язковим використанням попереднього позитивного досвіду, а також урахуванням попередніх прорахунків в організаційно-правових засадах проведення виборів депутатів до Верховної Ради України.

Формування цілей. Мета й завдання цієї розвідки полягають у розкритті алгоритму змін виборчої системи до українського парламенту впродовж періоду незалежності, узагальненні досвіду та його використанні для вирішення сучасних проблем реформування виборчої системи до вищого законодавчого органу влади в країні.

Виклад основного матеріалу. Виборча система - це законодавчо встановлений спосіб висування кандидатів, голосування за них та визначення результатів виборів. При обранні виборчої системи треба враховувати національні конституційні та політичні особливості. У різних державах селекція типу виборчої системи залежить від елементів форми держави, системи балансу влади, структури парламенту, типу партійної 
системи, національного складу суспільства, традицій та культури, зовнішніх чинників [1].

Реформування виборчої системи до Верховної Ради України в досліджуваний період відбувалося поетапно. Перший етап продовжувався від липня 1990 року до вересня 1997 року, тобто з моменту ухвалення Декларації про Державний суверенітет до введення в Україні змішаної виборчої системи до законодавчого органу. У цей період у державі діяв парламент, сформований ще в березні 1990 року, у якому перевагу за кількістю депутатських місць ще тримала Комуністична партія. На виборах 1990 року майже третину місць вдалося вибороти Демократичному блоку, який невдовзі оголосив про перехід до конструктивної опозиції й оформився в Народну Раду. Склад законодавчого органу оновився порівняно 3 попереднім (XI скликання) на 90\%, що свідчило про з' явлення нової генерації політиків [2, с. 115-116]. На цьому етапі відбулося становлення мажоритарної виборчої системи для обрання депутатів Верховної Ради України, яка частково успадкувала елементи ще попередньої, що регулювалася радянським нормативно-правовим актом. Відповідно до Закону України від 18 листопада 1993 року № 3623-XII вибори проводилися в 450 одномандатних виборчих округах на основі абсолютної більшості. Мажоритарна система абсолютної більшості - це виборча система, відповідно до якої переможцем стає кандидат, який отримає мінімум 50\% плюс один голос. Якщо ніхто 3 кандидатів не набирав абсолютної більшості, тоді проводився другий тур, до якого виходять два кандидати, які набрали більше голосів, ніж інші кандидати в депутати. Основним недоліком цієї системи є те, що втрачаються голоси тих виборців, хто голосував за кандидатів, які програли виборчі перегони. Крім того, під час проведення другого туру за мажоритарною системою абсолютної більшості найчастіше, з огляду на зменшення мотивації громадян у голосуванні, знижується поріг участі виборців. Проте такий досвід не було враховано у вітчизняному законі 1993 року. За результатами виборів 1994 року склад Верховної Ради України виявився доволі строкатим за наявності великої кількості безпартійних кандидатів попри те, що серед них були представники 12 політичних партій. Недосконале структурування негативно позначилося на ефективності діяльності законодавчого органу держави. Також зазначимо, що склад Верховної Ради України II скликання найбільше дообирався за час своєї роботи та до кінця каденції не працював у повному складі. Після прийняття Конституції України Верховна Рада України активізувала роботу над ухваленням Закону про вибори народних депутатів. Між політичними партіями розгорнулася дискусія щодо питання про модель виборчої системи. До Верховної Ради надійшло чотири варіанти Закону про вибори, три з яких пропонували змішану (мажоритарно-пропорційну) систему. Саме ці проекти стали основою тексту Закону про вибори народних депутатів на основі принципів змішаної системи.

Другий етап фактично розпочався після ухвалення нового Закону України «Про вибори народних депутатів України» від 24 вересня 1997 року № 541/97-ВР й продовжувався до липня 2005 року - моменту внесення 
суттєвих змін до нового нормативно-правового акта щодо проведення виборів до парламенту. Упродовж цього періоду вибори до Верховної Ради України проводилися двічі - у 1998 та 2002 роках за змішаною виборчою системою. В Україні змішана виборча система існувала у варіанті, коли 225 депутатів (половина складу парламенту) обиралися в одномандатних округах, і стільки ж - за списками кандидатів від партій і виборчих блоків у багатомандатному загальнодержавному виборчому окрузі на основі пропорційного представництва. Однією 3 відмінностей проведення зазначених виборів можна вважати різний загороджувальний пункт. Аби брати участь у розподілі депутатських місць у багатомандатному виборчому окрузі, політична сила мала набрати певний мінімум голосів - 4\% у 1998 році та 3\% у 2002 році. Позитивним у проведенні виборів в одномандатних округах стало застосування мажоритарної системи відносної більшості. Це найбільш проста та розповсюджена система, за якої для перемоги кандидатові досить отримати на один голос більше, ніж у конкурента, що давало змогу провести вибори в один тур. Другий етап реформування виборчої системи до законодавчого органу влади вважаємо проміжним, оскільки упродовж його дії не було остаточно подолано багатьох недоліків попередньої виборчої системи. Підтвердженням цього факту є суттєва різниця результатів голосування в мажоритарних округах та загальнодержавному виборчому окрузі, що не впливало позитивно на політичне структурування Верховної Ради України.

Парламентські вибори 2002 року мали шанс увійти у вітчизняну історію як приклад успішного демократичного вирішення конфлікту кінця 2000 початку 2001 року між владою й опозицією. Зауважимо, що за рік до виборів він почав набувати непарламентських форм. Проте блок «За Єдину Україну», реально посівши в загальнонаціональному багатомандатному виборчому окрузі лише третє місце (менше 12\%) і програвши навіть радикальній опозиції (СПУ і Блок Юлії Тимошенко разом здобули симпатії понад 14\% виборців), позиціонував себе як переможця виборів через створення найбільшої фракції в парламенті внаслідок залучення депутатівмажоритарників, величезна частка яких йшла на вибори самовисуванцями, a не кандидатами блоку. Влада знову, як i в радянські часи, продемонструвала суспільству, що останнє слово залишається за нею, а не за тими, хто ії обирає. Це мало виправдання лише з погляду самовиживання тодішнього політичного режиму, але аж ніяк не сприяло подоланню соціально-психологічної депресії, вирішенню соціально-економічних проблем і дальшій демократизації суспільства, стабільності та злагоді.

Відсутність належної політичної культури в суспільстві, готовності 3 боку опозиції та влади визнавати свою поразку, а також небажання останньої рахуватися 3 результатами волевиявлення громадян спричинили низку негативних наслідків у процесі виборів 2002 року. По-перше, йдеться про нетолерантну політичну дискусію між блоком влади і опозицією; по-друге, спроби грубого маніпулювання громадською думкою через державні й підконтрольні ЗМІ, а також адміністративного тиску на виборців і опонентів; по-третє, післявиборчі спроби перегляду результатів голосування як в окремих мажоритарних округах, що виявилися в невизнанні результатів 
виборів лише в тих 3 них, де перемогли опозиційні кандидати, так і в загальнонаціональному масштабі, через нав' язування суспільству думки про перемогу владного блоку.

Зазначене стало одним із мотивів ухвалення змін до законодавства, що стосується виборів до українського парламенту, а саме: Верховна Рада України схвалила зміни, які були закріплені в Законі України «Про внесення змін до Закону України «Про вибори народних депутатів України» від 07 липня 2005 року № 2777-IV [3].

3 цього моменту (хоча й дещо відносно) почався третій етап у процесі зміни та становлення в Україні нової пропорційної виборчої системи до вітчизняного законодавчого органу держави. Суть цієї виборчої системи полягає в тому, що місця в представницькому органі розподіляються між партійними силами пропорційно поданих за них голосів. Ця система найбільш точно відображає переваги, які електорат надає тій чи іншій політичній партії. Зауважимо, що спроби переходу виборчої системи до пропорційної були й раніше, наприклад, напередодні виборів до Верховної Ради України 2002 року, але позиція Президента України, його право «вето» поставили крапку в цьому питанні в цей період. Кульмінацією дальшого переходу до пропорційної виборчої системи стало ухвалення Верховною Радою України Закону України «Про внесення змін до Конституції України» від 08 грудня 2004 року № 2222-IV. Прикінцеві та перехідні положення цього нормативно-правового акта чітко фіксували обрання наступного складу народних депутатів у 2006 році на основі загального, рівного і прямого виборчого права на засадах пропорційної системи в багатомандатному загальнодержавному виборчому окрузі за виборчими списками кандидатів від різних політичних партій та блоків [4]. Вибори до Верховної Ради України за пропорційною виборчою системою відбулися двічі: в березні 2006 року - чергові та вересні 2007 року - позачергові. Відсотковий бар'єр двічі застосовувався однаковий - 3\%. Однією з негативних ознак пропорційної виборчої системи є голосування виборців за партійний список, до якого можуть входити невідомі та непопулярні політики. В Україні цей недолік було поглиблено закритими списками: до відома виборців доводилися лише перші п'ять прізвищ, інші ж для електорату були невідомі. Крім того, парламент, обраний за таких обставин, не відповідав принципам регіонального представництва. Зокрема, серед 450 народних обранців за результатами виборів 2007 року в Києві проживало майже 61 \% від загальної кількості, тоді як частка киян серед населення України становить приблизно 6 \% [5]. Отже, третій етап реформування виборчої системи до законодавчої інституції в Україні, з одного боку, ставив нашу державу на одну сходинку 3 європейськими країнами (Естонією, Польщею, Чехією тощо), а з іншого, - не виправдовував очікуваних сподівань.

Перед аналізом четвертого етапу реформування виборчої системи до українського парламенту зазначимо, що органи державної влади в Україні неодноразово отримували рекомендації Місії зі спостереження за виборами ОБСС /БДІПЛ щодо ухвалення виборчого кодексу. У березні 2010 року група народних депутатів Верховної Ради України внесла на розгляд парламенту 
проект Виборчого кодексу України (реєстр. № 4234-1), який, за висновком Венеціанської комісії, мав стати позитивним каталізатором реалізації виборчої реформи та інтеграції міжнародного досвіду в процесі виборчих перегонів до вітчизняного законодавчого органу. Але чинна на тоді влада на чолі з Президентом України створила 02 листопада 2010 року Робочу групу 3 питань удосконалення законодавства про вибори, яка, своєю чергою, напрацювала проект нової редакції Закону «Про вибори народних депутатів України». Однією з ключових проблем доопрацьованого проекту закону стало повернення до змішаної виборчої системи, яка застосовувалась у 1998 та 2002 роках [6]. У результаті Верховна Рада України ухвалила новий Закон України «Про вибори народних депутатів Украӥни» від 17 листопада 2011 року № 4061-VI. На цьому етапі трансформації виборчої системи до вітчизняного парламенту вибори проводилися двічі: у жовтні 2012 року (чергові) та жовтні 2014 року (позачергові). Зміни у виборчому законодавстві, що повертають вітчизняний парламент до виборчої системи, яка за час дії (1998р., 2002 р.) існувала та не виправдала себе, посилюють враження, що очільники держави зайшли в глухий кут, або свідомо проводили маніпуляції з виборчим законодавством. Відволікаючи громадські організації обговоренням технічних складових законопроекту - відсотки прохідного порогу, можливість брати участь у виборах блоків партій, порядок формування виборчих комісій тощо - влада легітимізувала сутність самої виборчої системи, яка виявилася помилковою у своїй основі [7]. Отже, недоліки вітчизняної системи виборів до Верховної Ради України другого етапу їі становлення в правовому полі перейшли до четвертого етапу.

Суттєва проблема, з якою українське суспільство стикається не вперше, - нестабільність виборчого законодавства. У нашій державі склалася «цікава» практика ухвалення нового Закону України стосовно виборів народних депутатів напередодні виборчого процесу та під окрему виборчу кампанію. Це аж ніяк не сприяє проходженню нормативно-правовим актом експертизи на його відповідність реаліям часу, а вдосконалення нового Закону відбувається безпосередньо на марші [8, с. 18]. Йде вже п'ятий рік з часу проведення останніх виборів до Верховної Ради України, але впевнено спрогнозувати виборчу систему, яка буде застосована на виборчих перегонах (попередньо 27 жовтня поточного року) на сьогодні важко. Хоча ще в листопаді 2014 року парламент ухвалив коаліційну угоду, у шостому розділі якої упродовж першого кварталу 2015 року передбачено реформування парламентської системи виборів, - перехід від змішаної (пропорційномажоритарної) до пропорційної виборчої системи з відкритими списками. За цією системою виборці голосували б за конкретних кандидатів у багатомандатних виборчих округах. Також угодою визначено забезпечення на законодавчому рівні відповідальності суб'єктів виборчого процесу за порушення норм виборчого законодавства та посилення відповідальності політичних партій у разі недотримання вимог щодо прозорості фінансування їхньої діяльності [9]. Конкретним результатом зазначеної угоди можна вважати ухвалення 07 листопада 2017 року в першому читанні проекту Виборчого кодексу України. Нагальна потреба ухвалення цього важливого нормативно-правового акта неодноразово обговорювалась. 
Створення єдиних позицій забезпечення нормативного регулювання виборів глави держави, депутатів місцевого рівня та депутатів Верховної Ради України є загальновизнаною. Парламентська Асамблея Ради Європи, Свропейська Комісія «За демократію через право» (Венеціанська комісія), Бюро 3 демократичних інституцій та прав людини ОБСЄ також неодноразово звертали увагу на необхідність розробки та ухвалення Виборчого кодексу України [10]. Сподіваємось, що можливе ухвалення в остаточній редакції та набрання чинності зазначеного закону започаткують п'ятий етап трансформації виборчого законодавства до вітчизняного парламенту. Зауважимо, що суспільство відчує більшість переваг пропорційної виборчої системи з відкритими списками, а серед кандидатів у депутати суттєво посилиться внутрішньопартійна конкуренція за підтримку саме голосів електорату, а не можливості будь-якого іншого впливу на отримання депутатських повноважень.

Висновки. Констатуємо, що складний, але реальний шлях формування вищого законодавчого органу влади в Україні, проведення вільних та прозорих виборів до нього є одним 3 найяскравіших показників дійсного демократизму наявного в країні політичного ладу, головним критерієм його легітимності. Трансформацію виборчої системи до Верховної Ради України можна розділити на чотири основні етапи відповідно до моделі, за якою відбувалося висування та обрання народних депутатів вітчизняного представницького органу влади. У сучасних умовах першочергове значення також набуває проведення в життя змістовного аспекту представництва, яке охоплює зростання політичної культури депутатського корпусу та вироблення чіткої функціональної концепції ролі самого депутата. Усі типи виборчої системи тією чи іншою мірою містять позитивні та негативні елементи. Держава перебуває на шляху повернення до пропорційної виборчої системи з урахуванням подолання недоліків, притаманних виборчим кампаніям 2006 та 2007 років. Попри те, що остаточну ефективність пропорційної виборчої системи з відкритими списками, з ї̈ перевагами та недоліками, в Україні може підтвердити винятково виборча практика, на сьогодні склалися певні передумови ії запровадження. Але чи вистачить у владної еліти політичної волі на ухвалення цього важливого для нашої країни рішення побачимо вже восени поточного року.

\section{Використані джерела:}

1. Афанасьєва М. В. Критерії законодавчого проектування виборчої системи. Вісник Національного технічного університету України "Київський політехнічний інститут». Політологія. Соиіологія. Право. 2012. № 2. С. 90-97. URL: http://visnykpsp.kpi.ua/article/view/123324/118033 (дата звернення: 01.03.2019).

2. Литвин В. Політична арена України: Дійові особи та виконавці : монографія. Київ: Абрис, 1994. 495 с.

3. «Про внесення змін до Закону України «Про вибори народних депутатів України» від 07 липня 2005 року № 2777-IV. Відомості Верховної Ради України. 2005. № 38(38-39). Ст. 449.

4. Про внесення змін до Конституції України : Закон України від 08.12.2004 № 2222-IV. Відомості Верховної Ради України. 2005. № 2. Ст. 44. 
5. Ставнійчук М. «Закрита» виборча система вичерпала себе. URL: https://dt.ua/POLITICS/zakrita_viborcha_sistema (дата звернення 27.11.2018).

6. Стандарти виборчого законодавства, недоліки та їх усунення. Лабораторія законодавчих ініціатив. Съомий Київський діалог. Вибори - Партї - Політичні рухи : матеріали конф., м. Київ, 2-3 червня 2011 р. Київ, 2011. URL: http://pauci.org/upload/files/dialog_all18112011-final.pdf (дата звернення: 01.03.2019).

7. Чумак В. Вгору по драбині, що веде донизу... Про деградацію виборчої системи в Україні. Дзеркало тижня. 2011. 3-10 черв. (№ 20). URL: https://dt.ua/POLITICS/vgoru_po_drabini,_scho_vede_donizu_pro_degradatsiyu_vibo rchoyi_sistemi_v_ukrayini.html (дата звернення: 10.12.2018).

8. Давидович Я. В. Поглиблення демократизації виборчих процесів в Україні: особливості проведення парламентських виборів 2006 року. Вісник Центральної виборчої комісії. 2006. № 4(6). С. 16-21.

9. Угода про Коаліцію депутатських фракцій «Европейська Україна»: Угода від 27.11.2014 № n0001001-15. URL: https://zakon3.rada.gov.ua/laws/show/n0001001-15 (дата звернення: 01.03.2019).

10. Пояснювальна записка до проекту Виборчого кодексу України 3112-1 від 02.10.2015. URL: http://w1.c1.rada.gov.ua/pls/zweb2 (дата звернення: 01.03.2019).

Стаття надіӥшла до редколегіï 10.03.2019

Пекарчук В. М., доктор исторических наук, доцент, профессор кафедры теории и истории государства и права, конституционного права Академии Государственной пенитенциарной службы (г. Чернигов, Украина)

Пекарчук А. В., студентка 2 курса Института прокуратуры и уголовной юстиции Национального юридического университета имени Ярослава Мудрого (г. Харьков, Украина)

Трансформация избирательной системы Верховной Рады Украины периода независимости

В статье на основе разноплановых источников исследуются актуальные вопросы избирательной системы в отечественный парламент на протяжении современного периода независимости, и на этой основе внедрения более эффективной модели - пропорциональной избирательной системы с открытыми списками. Проанализированы недостатки парламентской избирательной системы на разных этапах ее становления и развития. Обоснована необходимость безотлагательного принятия Избирательного кодекса Украины для создания единых позиций обеспечения нормативного регулирования института выборов.

Ключевые слова: Верховная Рада Украины, выборы, избирательная система, закон, избирательный процесс, парламент, избирательный барьер.

Pekarchuk V., Pekarchuk A. Transformation of the Election System of the Verkhovna Rada of Ukraine since Independence

In the article the author researches the essential issues of the election system of the national parliament during the modern period of independence on the basis of the wide range of sourses. The author analyzes the drawbacks at the different stages of establishing and developing the parliamentary election system. The author points out that the Ukrainian society constantly faces the unstable election legislation. There is a practice of adopting a new Act of Ukraine as to the election of national deputies on the eve of the election process and for a certain election campaign in the state. 
The author stresses that when there is no proper political culture in the society, when the opposition and authorities don't take into account the results of the expression of the electors'will, a number of negative consequences occur while elections are held i.e. intolerant political discussion between the authorities and the opposition, attempts of a rude manipulation of the public thought using the state and controlled mass media, administrative pressure on electors and opponents, attempts to revise the elections results in particular majority electoral districts where opposition candidates have won as well as in the whole country by persuading the society that the authoritative block has won.

The author finds out that the transformation of the election system of the Verkhovna Rada of Ukraine can be divided into four main stages according to the model of nomination and election of national deputies to the national representative body of power. At present implementation of the profound aspect of the representation that includes improving the national deputies' political culture and developing a clear functional conception of a deputy's role is of great importance. All types of the election system comprise positive and negative sides. The author stresses that the state is at the edge of returning to a proportional election system that takes into account overcoming the drawbacks which are characteristic for election compaigns of previous years. The author outlines the importance of the urgent adoption of the Election Code of Ukraine in order to establish the united positions of ensuring the normative regulation of the institute of elections.

Key words: Verkhovna Rada of Ukraine, elections, election system, act, election process parliament, election barrier.

УДК 342.729

Самбор М.А.

кандидат юридичних наук, начальник сектора моніторингу Прилуцького відділу поліції Головного управління Національної поліції В Чернігівській області (м. Чернігів, Україна)

\section{ПРАВО НА СВОБОДУ МИРНИХ ЗІБРАНЬ В УКРӒ̈НІ: ЕВОЛЮЦІЯ КОНСТИТУЦЙНИХ НОРМ ПРОТЯГОМ СТОЛІТТЯ}

У статті досліджено еволюцію конституційних норм щодо врегулювання здійснення та інституалізації права на свободу мирних зібрань в Україні. Проаналізовано норми чотирьох Конституцій УРСР та Конституції України щодо закріплення права на свободу мирних зібрань і формулювання змісту згаданого права. Зазначено, що розвиток громадянського суспільства суттєво позначатиметься на розумінні та здійсненні права на свободу мирних зібрань, а тому твердити про абсолютну визначеність та усталеність цього правового явища не доречно, оскільки правова практика, законотворчість правозастосування вноситимуть до права на свободу мирних зібрань свої особливості, які можуть набути сталих рис і привести до їх нормативно-правового закріплення.

Ключові слова: конституція, право на свободу мирних зібрань, конституційна норма, інституалізація (закріплення) права на свободу мирних зібрань у Конституції. 